\title{
Comparison of Bone Graft Healing Between Autogenous Bone, Blood Clot and Anorganic Bovine Bone Matrix. Radiographic and Histological Analyses
}

\author{
Comparasión de la Reparación de Injertos Óseos entre Hueso Autógeno, Coágulo \\ Sanguíneo y Matriz Ósea Bovina Anorgánica. Análisis Histológico y Radiográfico
}

\author{
Sergio Olate ${ }^{*, * *}$; Henrique Duque Netto ${ }^{* * *}$; Leandro E. Klüppel ${ }^{* * * *}$; Bélgica Vásquez ${ }^{* * * * * *}$; \\ Maria das Graças A. Miranda Chaves**** \& Mariano del Sol*
}

OLATE, S.; DUQUE NETTO, H.; KLÜPPEL, L. E.; VÁSQUEZ, B.; MIRANDA CHAVES, M. G. A. \& DEL SOL, M. Comparison of bone graft healing between autogenous bone, blood clot and anorganic bovine bone matrix. Radiographic and histological analyses. Int. J. Morphol., 31(4):1257-1262, 2013.

SUMMARY: Surgical procedures involving the rehabilitation of the maxillofacial region frequently require use of bone grafts. Bone graft follow-up is generally done through clinical analysis and especially through image tests, although few studies specifically correlate both. The object of this research was to establish a relation between radiographic exams and the bone repair process stage in created defect with autogenous bone, blood clot and anorganic bovine bone matrix. Three $8 \mathrm{~mm}$ diameter defects were performed in the parietal bone of 6 male adult beagle dogs, choosing the selected graft for each defects; 3 and 6 week period were used for radiographic and histological analyses. The result show that autogenous bone and blood clot were similar between histological and radiograph analyses; for heterogeneous bone was present areas described how bone in radiograph that were residual particles in histological exam. We concluded that radiographic tests could be used as a parameter for reconstruction follow-up only when autogenous bone graft is used.

KEY WORDS: Autogenous bone; Biomaterials; Bone graft.

\section{INTRODUCTION}

Surgical procedures involving the maxillofacial region frequently require bone grafts for reconstructing congenital or acquired deformities, as well as for skeletal corrections for aesthetic purposes (Jensen \& SindetPedersen, 1991). Thus, after reconstructive procedures take place grafts go through a number of events culminating in their incorporation by the recipient bed. This graft incorporation process happens dynamically through reabsorption and apposition of the new bone formation (Nunamaker, 1998).

Graft follow-up is generally done through clinical analysis and especially through image tests such as radiography and tomography (Serra e Silva et al., 2006), even though these are not reliable as to the quality of the graft that is being assessed. The histological test is the gold standard to assess bone tissue quality that forms in the grafted area (Pallesen et al., 2002).

Amongst the material used in bone grafting, autogenous graft is considered the gold standard for reconstructions because it has properties such as osteoinduction, osteoconduction and osteogenesis. Despite that, a donor site is necessary increasing surgical morbidity as well as limited bone volume (Kübler et al., 2004). For that reason, bone replacements are being developed and researched. Among these, anorganic bovine bone matrix is the most widely used both for its many years of research and its known osteoconductive potential (Callan \& Rohrer, 1993; Hass et al. 2002; Jensen et al., 2006).

\footnotetext{
Division of Oral and Maxillofacial Surgery and CIMA, Universidad de La Frontera, Chile.

** Center for Biomedical Research, Universidad Autónoma de Chile, Chile.

*** Division of Oral and Maxillofacial Surgery, Federal University of Juiz de Fora, Brazil.

***** Dental School, State University of Ponta Grossa, Brazil.

******* Universidad de Tarapacá, Chile.

Parcialmente Financiado por Proyecto DIUFRO DI12-0015
} 
Thus, the object of this research is to establish a clinical relation between radiographic and histological tests in cases of autogenous and heterogenous graft follow-up (anorganic bovine bone matrix).

\section{MATERIAL AND METHOD}

This research was approved by the Ethic Commission for Animal Experimentation of Campinas State University under protocol number 1343-1; was executed an animal study creating 3 defects performed in the parietal bones of 6 male adult dogs weighting $15 \mathrm{~kg}$ as described below.

Preoperative. Thirty minutes before the procedure the animals received intramuscular dexamethasone $(0.5 \mathrm{mg} / \mathrm{kg})$ and $0.1 \mathrm{ml} / \mathrm{kg}$ weight of benzathine benzylpenicillin as an antibiotic prophylaxis. Before the surgical procedures, the animals were sedated with the anesthetic inductor ketamine chlorohydrate $(0.15 \mathrm{~mL} / \mathrm{kg})$ and underwent general anesthesia receiving a $3 \%$ pentobarbital sodium $(30 \mathrm{mg} / \mathrm{kg})$ intravenous application.

Surgical procedure. For this research, 3 cavities were created in parietal regions with a $8-\mathrm{mm}$ wide trephine bur; the dura mater integrity was preserved with carefully management of bone block when was extracted. The selected area was randomized by right or left side considered cavities number one, two or three.

Bone fragments that were removed were ground in the bone grinder and kept hydrated in a $0.9 \%$ physiological saline solution before its use.

Cavity area was almost around $5 \mathrm{~mm}$ of height and 8 mm wide. Filling was randomly done. One was filled with blood clot (Group I), another with 750 to $1000 \mathrm{~mm}$ ground autogenous bone (Group II), and yet another with 450 a 749 $\mathrm{mm}$ anorganic bovine bone matrix (Group III).

After cavity filling, periosteum and temporal muscles were approximated with sutures by using absorbable stitch (polyglactin 910). Superficial planes were sutured with 4-0 monofilament nylon stitch.

Euthanasia and sampling. Animals were randomly divided into two groups corresponding to the two euthanasia periods: the first group consisted of 3 animals which were euthanized three weeks after surgical procedure; the second group with 3 animals were euthanized six weeks after surgical procedure. Sacrificing took place with a $19.1 \%$ potassium chloride intravenous overdose until cardiorespiratory arrest. Following this stage, access to the animal's skull was created and the grafted region exposed.

Bone blocks were obtained by cross and coronal sectioning of the bone with a 702 tapered drill in high-speed turbine under constant saline solution irrigation with a 10$\mathrm{mm}$ safety margin for the previously operated areas. After that, a single periapical film (F sensibility) was used to take the radiographies taken on a perpendicularly position, 10 centimeters far from the blocks. The technique was performed using a same radiographic machine with the regulation of $60 \mathrm{KV}$ e $10 \mathrm{~mA}$ and 0,25 seconds of exposure time. All films were reveled in automatic process revelation machine using the T-mat type chemical solutions. The total revelation period was 7 minutes for each radiographic film.

The material was prepared with a histological routine technique using hematoxilin-eusin for lamina preparation. The blocks were sagittal cut on two identical parts, obtaining 5 serial laminas with $6 \mathrm{~mm}$ of thick.

Radiologic Analysis. Radiographic images were comparatively analyzed between the prepared bone- defect region and the intact bone area around the defects (control area) by correlating radiographic density in the central and peripheral regions. The analysis was realized as double blind by a oral and maxillofacial radiologist with 5 year of experience without know of the time or material graft.

Histological Analysis. The descriptive method was used for histological analysis and bone regeneration patterns were assessed such as: presence of inflammatory reaction and conditions involving bone repair of circular defects. Events and tissue characteristics in the bone repair process were described as necrosis, hemorrhage, osteoclast and osteoblast activities, presence of connective tissue and maturation degree, presence of grafted material remnants, as well as new bone tissue formation.

\section{RESULTS}

3 Weeks Group I - Clot. Radiological assessment suggests a well demarcated cavity with a considerably smaller radioopacity in the central (CA) and peripheral (PA) regions when compared to pre- existing (PB) bone tissue, as shown in Figure 1A. Through the histological analysis, connective tissue (CT) was observed to fill the surgical cavity almost 
completely, and the surrounding region (PB) was well demarcated. The region in the defect borders shows remodeling areas with a bone reabsorption and apposition, as well as dense connective tissue (DCT). Amidst the newly formed conjunctive tissue there is a discreet inflammatory process (IP) and some blood vessels (BV). Newly formed bone tissue was not observed (Fig. 1B).

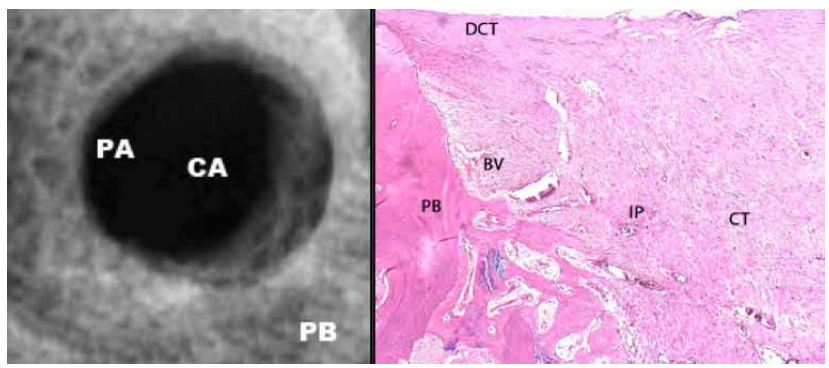

Fig. 1. Radiography and histological analysis (10x) for Group I within a 3-week period. Note that both indicate a repair process still with no newly formed bone tissue.

3 Weeks Group II - Autogenous bone graft. Radiological assessment showed a well demarcated and totally filled cavity with radio-opaque areas inside (CA), a finding that is compatible with the graft compaction in the trans-operative. Although these grafts showed some less demarcated regions, autogenous bone particles are evident as well as the defect surrounding area (PA), as shown in Figure 2A. In the histological analysis we could identify the limiting regions between pre-existing bone and graft (PB). Defect margins showed remodeling areas and new centripetal bone formation (Fig. 2B). Also was observed fibrous connective tissue (CT) crossing newly formed bone (A), as well as revascularization areas and some remnants of grafted bone tissue (BG).

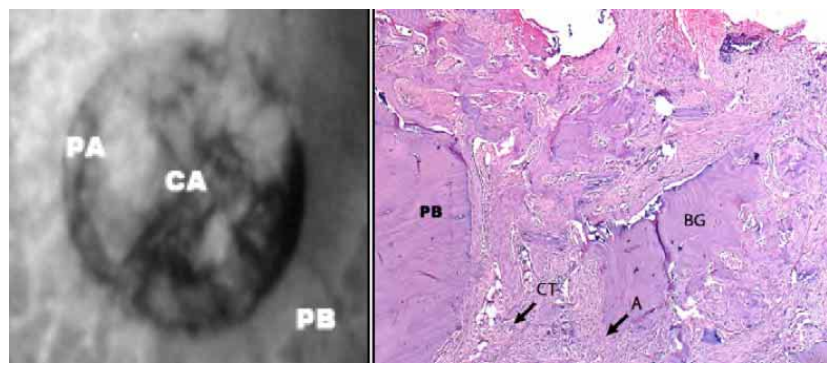

Fig. 2. Radiography and histological analysis (10x) for Group II within a 3-week period. Note that both indicate a more advanced repair process than Group I, which suggests regions of newly formed bone tissue in both analyses (A).

3 Weeks Group III - Anorganic bovine bone matrix. Radiological assessment showed a clear contour in the bone defect (CA), which is visibly more radiolucent than the adjacent bone tissue (PB) although it shows radiopaque points inside (CA), as shown in Figure 3A. In histological sections there is fibrous connective tissue (CT) almost entirely filling the surgical cavity. Few newly formed and still immature bone trabeculae were found interspersed by the fibrous conjunctive tissue and blood vessels (BV). Defect border was clear (PB) and showed remodeling areas in the defect margins. Some remaining particles were found from the material used for cavity filling (BG). The group also showed a discreet inflammatory process (Fig. 3B).

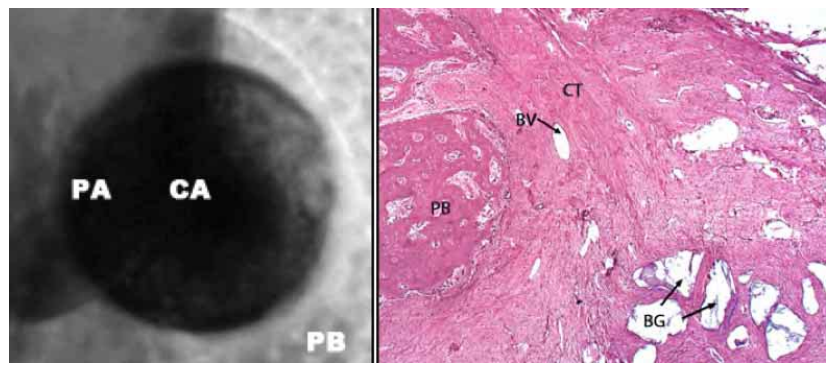

Fig. 3. Radiography and histological analysis (10x) for Group III within a 3-week period. Note that the histological analysis shows calcified material inside. This does not represent a newly formed bone tissue but particles from the grafted material.

6 Weeks Group I - Clot. Radiological analysis showed a decreased limit demarcation between defect (PA) and preexisting bone (PB) when compared to the 3-week period, as well as a decreased radiolucency relating to the clot region (CA) especially in the regions surrounding the defect (Fig. 4A). Histologically, the pre-existing bone (PB) was still clear and the central region showed good cellularity and vascularization (BV). In the surgical bone cavity margins, remodeling areas were observed in the pre-existing bone and the newly formed bone (NB) in a centripetal direction. In the central portion, there was fibrous connective tissue (CT) interspersed with some newly formed bone trabeculae (Fig. 4B).

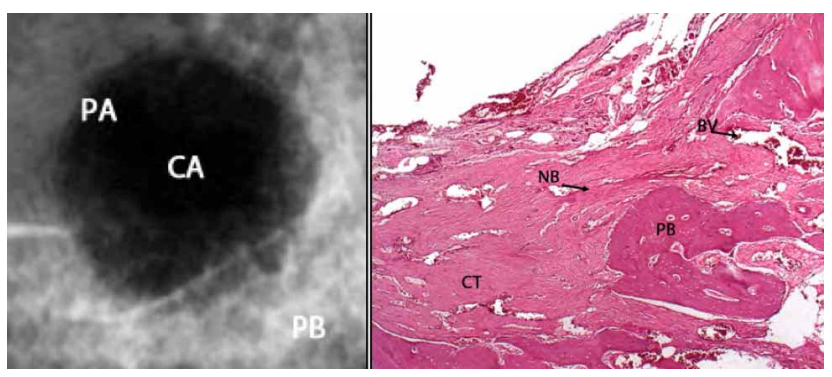

Fig. 4. Radiography and histological analysis (10x) for Group I within a 6-week period. The histological analysis showed some remodeling in the peripheral region and the presence of newly formed bone tissue, just as suggested by the radiological analysis.

6 Weeks Group II - Autogenous bone graft. The radiological analysis shows that the ostectomy is virtually 
unnoticed and its filling shows radio-opacity similar to the adjacent bone (PB), yet still scattered and with an undefined and amorphous trabeculate with points of mineralization in the central (CA) and peripheral (PA) regions, as shown in Figure 5A. The histological analysis showed that the surgical cavity was almost entirely filled with newly formed bone trabeculae (NB) interspersed by some areas of fibrous connective tissue (CT) and medullary bone tissue (MBT). Defect borders were not well demarcated (PB). The inside of the newly formed bone tissue showed some particles from the graft that was used to fill the surgical cavity and also some blood vessels (BV). The margins of this pre-existing bone tissue showed remodeling and new bone formation areas, and its growth was considered centripetal. Analyzing the graft shows a more advanced state of bone regeneration because this was the basis for the development of the replacement-regeneration process (Fig. 5B).

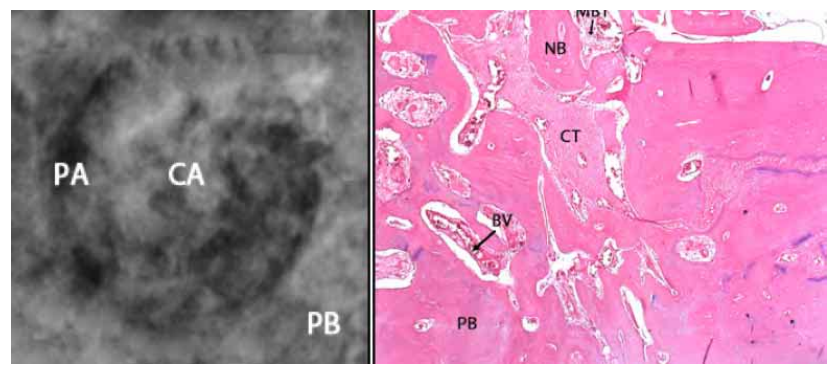

Fig. 5. Radiography and histological analysis (10x) for Group II within a 6-week period. Note that both analyses converge towards the presence of mature bone tissue with no clinical difference between the pre-existing region and the newly formed bone tissue.

6 Weeks Group III - Anorganic bovine bone matrix. The radiographic test showed clear contours in bone defect (PA). The defect showed a visibly more radiopaque image, especially in the central region (CA), which suggests the onset of a centrifugal bone repair process (Fig. 6A). The histological analysis showed advanced vascularization (BV) in the filling site and the start of bone tissue formation (NB). The process was in a more advanced new bone formation stage but some grafted material (BG) fragments are still found. However, these fragments show clear signs of an intense and varied reabsorption process with some particles almost entirely reabsorbed while others only partially. These particles are surrounded by connective tissue (CT) interspersed by newly formed bone tissue. The limit between the surgical bone cavity and the pre-existing bone (PB) was easily identified. In its periphery, the preexisting bone tissue showed remodeling and new centripetal bone formation areas. Also, a discreet inflammatory process was found, especially around these particles for the bone substitute that was used (Fig. 6B).

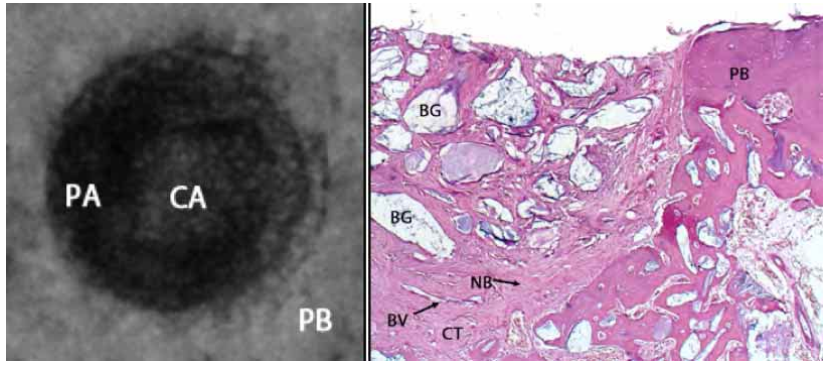

Fig. 6. Radiography and histological analysis (10x) for Group III within a 6-week period. Note that although the radiological image suggests new bone formation in the defect area, there is still little newly formed bone tissue as per the histological analysis.

\section{DISCUSSION}

Using imaging tests such as radiographies and computed tomographies for post-operative follow-up in surgical procedures is common. Although tomographic tests have a greater resolution and adequately image software analyses, radiographic tests have a similar efficacy for surgery follow-up (Ferrús-Torres et al., 2009). Thus, this research used periapical radiographies because they have a better distortion when compared to other radiographic tests (Dudic et al., 2008) besides providing diagnostic efficacy.

Several studies have used radiographic tests followup in bone reconstruction surgery and have showed satisfactory results (Callan \& Rohrer; De Boever \& De Boever, 2005). Gielkens et al. (2008) realized a comparison between microradiography, micro-computed tomography and histomorphometry conclude that microradiography and micro-computed tomography should be used in combination; for other hand, the authors conclude that image devices are better in graft widths measurement than defect measurement

Radiographies serve as parameters to quantitatively assess bone condition in post- operative periods (Rosenwasser et al., 1994). This research showed similar results when assessing autogenous bone or blood clot grafted areas in $8 \mathrm{~mm}$ cavities. In spite of that, the radiographic analysis of heterogenous grafts was different in the histological analysis for both euthanasia periods.

Our results detected that in cases of autogenous graft reconstruction the image tests were shown to be efficient because the results for radiographic and histological tests were similar in both euthanasia periods. For the 3 -week period, internal radiopaque areas can be seen in the radiographic analysis, suggesting grafted material and newly formed bone tissue, as well as radio-opacity similar to the 
adjacent bone for the 6-week period. These findings are confirmed through histological analysis. On the other hand, results from this study also highlight the how likely it is that radiographic tests, and we observed that are insufficient to determine the quality of the newly formed bone tissue when an anorganic bovine bone matrix is used as osteoconductor.

Nolff et al. (2010), in a mandibular sheep model, demonstrated that conventional computed tomography was not suitable to evaluate bone formation and resorption of beta-TCP graft. In our sample, defects treated with finegrained bovine bone matrix have a radiolucent aspect at the end of the experimental periods, which could suggest little new bone formation. In fact, what happens is that the cavity is filled with immature bone tissue and highly reabsorbed grafted particles.

Although some research reported differences of radiopacity between different bone graft materials (Pekkan et al., 2012), the present research suggest that radiographic tests are inefficient for assessing tissue repair process when using non autogenous material; radiography analyses serve as a parameter in the follow-up for reconstructions when using autogenous bone grafts.

OLATE, S.; DUQUE NETTO, H.; KLÜPPEL, L. E.; VÁSQUEZ, B.; MIRANDA CHAVES, M. G. A. \& DEL SOL, M. Comparasión de la recuperación de injertos óseos entre hueso autógeno, coágulo sanguíneo y matriz ósea bovina anorgánica. Análisis hostológico y radiográfico. Int. J. Morphol., 31(4):1257-1262, 2013.

RESUMEN: Los procedimientos que envuelven la rehabilitación de la región maxilofacial frecuentemente requieren el uso de injertos óseos. El seguimiento de la evolución del injerto óseo frecuentemente es realizado con análisis clínico y especialmente a través de estudios de imágenes, aunque pocos estudios han correlacionado ambos. El objetivo de esta investigación fue establecer la relación entre radiografías y las etapas de la reparación ósea en defectos creados con hueso autógeno, coagulo sanguíneo y matriz ósea de hueso bovino. Tres defectos de $8 \mathrm{~mm}$ de diámetro fueron realizados en el parietal de 6 perros adultos, escogiendo el injerto seleccionado para cada defecto; 3 y 6 semanas después fueron realizados los estudios histológicos y radiográficos. Los resultados mostraron que el hueso autógeno y el coágulo sanguíneo presentaron semejanzas en los análisis histológico y radiográfico; para el hueso bovino se observó áreas decritas como hueso en la radiografia mientras realmente fueron partículas de hueso heterogeno descritas en el análisis histológico. Concluimos que el test radiográfico puede ser usado como parámetro para la reconstrucción y seguimiento preferentemente cuando es usado el injerto autógeno.

PALABRAS CLAVE: Hueso autógeno; Biomaterials; Injerto óseo.

\section{REFERENCES}

Callan, D., P. \& Rohrer, M. D. Use of bovine derived hydroxiapatite in the treatment of edentulous ridge deffects: a human clinical and histologic case report. J. Periodontol., 64(6):575-82, 1993.

De Boever, A. L. \& De Boever, J. A.. Guided bone regeneration around non-submerged implants in narrow alveolar ridges: a prospective long-term clinical study. Clin. Oral Implant Res., 16(5):549-56, 2005.

Dudic, A.; Giannopoulou, C.; Martinez, M.; Montet, X. \& Kiliaridis, S. Diagnostic accuracy of digitized periapical radiographs validated against micro-computed tomography scanning in evaluating orthodontically induced apical root resorption. Eur. J. Oral Sci., 116(5):467-72, 2008.

Ferrús-Torres, E.; Gargallo-Albiol, J.; Berini-Aytés, L. \& Gay Escoda, C. Diagnostic predictability of digital and conventional panoramic radiographs. Int. J. Oral Maxillofac. Surg., 38(11):1184-7, 2009.

Gielkens, P. F.; Schortinghuis, J.; de Jong, J. R.; Paans, A. M.; Ruben, J. L.; Raghoebar, G. M.; et al. The influence of barrier membranes on auologous bone graft. J. Dent. Res., 87(11):1048-52, 2008.
Haas, R.; Haidvogl, D.; Donath, K. \& Watzek, G. Freeze-dried homogeneous and heterogeneous bone for sinus augmentation in sheep: Part I - Histological findings. Clin. Oral Implant Res., 13(4): 396-404, 2002

Jensen, J. \& Sindet-Pedersen S. Autogenous mandibular bone grafts and osseointegrated implants for reconstruction of the severely atrophied maxilla: a preliminary report. J. Oral Maxillofac. Surg., 49(12):1277-87, 1991.

Jensen, S. S.; Broggini, N.; Hjorting-Hansen, E.; Schenk, R. \& Buser D. Bone healing and graft resorption of autograft, anorganic bovine bone B-tricalcium phosphate. A histologic and histomorphometric study in the mandible of minipigs. Clin. Oral Implant Res., 17(3):237-43, 2006.

Kübler, A.; Neugebauer, J.; Oh, J.; Scheer, M. \& Zöller, J. E. Growth and proliferation of human osteoblasts in different bone graft substitutes. An in vitro study. Implant Dent., 13(2): 171-9, 2004.

Nolff, M. C.; Kokemueller, H.; Hauschild, G.; Fehr, M.; Bormann, K. H.; Spalthoff, S.; et al. Comparison of computed tomography and microradiography for graft evaluation after reconstruction of critical size bone defects using beta-tricalcium 
OLATE, S.; DUQUE NETTO, H.; KLÜPPEL, L. E.; VÁSQUEZ, B.; MIRANDA CHAVES, M. G. A. \& DEL SOL, M. Comparison of bone graft healing between autogenous bone, blood clot and anorganic bovine bone matrix. Radiographic and histological analyses. Int. J. Morphol., 31(4):1257-1262, 2013.

phosphate. J. Craniomaxillofac. Surg., 38(1):38-46, 2010.

Nunamaker, D. M. Experimental models of fracture repair. Clin. Orthop. Relat. Res., 355 (Suppl):S56-65, 1998.

Pallesen, L.; Schou, S.; Aaboe, M.; Hjørting-Hansen, E.; Nattestad, A. \& Melsen F. Influence of particle size of autogenous bone grafts on the early stages of bone regeneration: a histologic and stereologic study in rabbit calvarium. Int. J. Oral Maxillofac. Implants, 17(4):498-506, 2002.

Pekkan, G.; Aktas, A. \& Pekkan, K. Comparative radiopacity of bone graft materials. J. Craniomaxillofac. Surg., 40(1):e1-4, 2012.

Serra e Silva, F., Ricardo de Albergaria Barbosa, J. \& Mazzonetto, R.. Clinical evaluation of association of bovine organic osseous matrix and bovine bone morphogenetic protein versus autogenous bone graft in sinus floor augmentation. J. Oral Maxillofac. Surg., 64(6):931-5, 2006.

Rosenwasser, M. P.; Garino, J. P.; Kiernan, H. A. \& Michelsen, C. B. Long term follow up of thorough debridement and cancellous bone grafting of the femoral head for avascular necrosis. Clin. Orthop. Relat. Res., 306(1):17-27, 1994.
Correspondence to:
Prof. Dr. Sergio Olate

Division of Oral and Maxillofacial Surgery

Universidad de La Frontera

Claro Solar No 115

Temuco - CHILE

Email: sergio.olate@ufrontera.cl

Received: 09-06-2013

Accepted: 13-10-2013 